\title{
The Quality of the Defence Administration
}

\author{
NAGY Sándor ${ }^{1}$
}

\begin{abstract}
All states have to have and run institutions, which provide services - such as mandatory state functions, which also result in Hungary being treated as an inde-pendent, sovereign Country - to each citizen, hopefully in the same way. Public safety, fire department, the armed forces of the country, healthcare and education can be mentioned as examples. The state runs a system to control the connecting directive and coordinating activities, which is called simply "public administra-tion". Obviously, it is essential to have a cost effective point of view of the man-power and the quality of the service in the administrative institution. Thus, it is needed to study the main purpose of the service given to the citizens to maintain the standard or to develop it, if needed — by public social needs. The main topic of this work is the quality of the administration but it studies only a tiny segment of it and the quality of the defence administration based on it.
\end{abstract}

\section{Introduction}

As can be seen in $21^{\text {st }}$ century Europe, rebuilt after the financial crisis in 2008, different coun- tries were affected financially in different ways. The countries had different backgrounds of course before the crisis so the result depended on the strength or weakness of their economy, when the first banks started to go bankrupt in the United States.

It is a recognizable tendency that recently the economy has become determinative in our World. It means if a country is rich, it can provide higher level services to its citizens, thus so- cial satisfaction grows concerning the state and the state apparatus. Most of the state income comes from taxes. Of course, as a member of the European Union we can get significant fi- nancial support, although, we have to pay in as well. As a result, a democratic country cannot be strong unless its economy works independently and the economy can be competitive if it is able to produce the same or better quality products at a lower price than the competitors abroad. The price-value rate is a question, which cannot be neglected in such a financial sit- uation and simply national awareness based economic-marketing cannot be really successful in the globalizing world.

The state income has been mentioned but we cannot forget expenses either. All states have to have and run institutions, which provide services — like mandatory state functions, which result in Hungary being treated as an independent, sovereign country — to each citizen, hopefully in the same way. Public safety, fire department, the armed forces of the country, healthcare and education can be mentioned as examples. The state runs a system to control the linking directive and coordinating activities, which is called simply "administration". Ob- viously, it is essential to have a cost effective point of view of manpower and the quality of

1 nagy.sandor1975@gmail.com 
the service in the administrative institution. It means even the richest countries cannot afford to have larger administrative institutional systems than is needed without any problems and there is a need to check the mandatory services of the state. Thus, it is needed to study the main purpose of the service given to the citizens, to maintain the standard or to develop it if needed

— by public social needs. The main topic of this work is the quality of the administration but it studies only a tiny segment of it and the quality of the defence administration based on it.

\section{Quality in General}

What is quality? It is an up-to-date and often discussed question with several answers and refutations. People studying it can be divided into two groups, those who think quality as a notion can be described and those who make a question of it.

Searching for the word in an encyclopaedia more descriptions can be found but we shall emphasize only one of them. Quality as a philosophical category means all the features which characterize the essence of things. [1] According to another approach, "quality is the confor- mance of a product or service (or even a process, system or anything else)". [2] Both descrip- tions show that quality is a bunch of properties which describe a given thing and it has to be examined from a given point of view.

Some philosophical trends say there is no substance without quality [3], which means the material described by the features is the material itself. If quality, is some feature that changes we get totally different material.

Quality as a notion appeared in leadership theory education as well. A significant member of the conventional quality-school, Philip Bayard Crosby says [4]:

- Quality means the adequacy to the needs and it is not elegance;

- Adequacy can be provided by prevention, not by assessment;

- Quality means zero fault;

- Quality can be measured by the cost of nonconformity.

Crosby is somewhat contradicted by William Edwards Deming, who said that control itself does not lead to quality, the quality of the product features the worker "who build it".

According to another conventional definition, by David Garvin, quality has different ap- proaches [5]:

- Transcendent: Quality is what passes the test. It means quality cannot be defined, it can be recognized only when it is seen;

- Product based: Quality is based on the presence or lack of a given feature. If a feature is expected, based on this definition, the more a feature describes the product or ser- vice, the more valuable it is;

- Production based: Quality is what the producer can produce with the given tools in the given environment if the product fits the agreed expectations or specifications. If it fails, it means some lack of quality;

- User based: Quality means we are able to satisfy the needs and expectations of our customers;

- Value based: Quality means that we offer products with given features for an accept- able cost and price;

- Standard based: Quality means the feature of the product which makes it adequate for the requirements of the standard. 
In brief it can be said that quality means all the features of an examined material, product or service, which make it able to satisfy the needs as expected.

\section{Defence Administration as a Service}

Defence administration is a duty and acting system based on public administration. Its only target is to provide the complex defence tasks of the state. There is no doubt, the support of population defence is in close connection with dangers, and our legal system divides dangers into two groups:

- military and disaster management administration.

The Fundamental Law of Hungary mentions five possibilities where the following dan- gers can happen (These are the special legal orders):

- State of National Crisis;

- State of Emergency;

- State of Preventive Defence;

- Unexpected Attack;

- State of Danger.

These terms are mentioned in the constitution as a special law and the military and de- fence law describes the special acts in such cases. The constitution before the fundamental law described these situations as qualified situations with more or less the same meaning. Most dangers have similar features because they threaten people, essential properties and created environment, directly or indirectly. Protection against dangers is a national duty and it is controlled by the state. Those who control protective acts save people's lives and prop- erties, such as the integrity of our country. They perform this by doing their duty according to their own responsibilities or according to the special laws of the term, if their peace-time concentrated power is not enough to avert dangers. At a central level, the power centre of defence administration changes according to the given, special laws (Military Council, Par- liament, Government), while defence administration is done by county defence committees at a rural level, such as local defence committees on the spot and mayors at municipal level according to their administrative power.

Let us examine the question from the point of view of the citizen itself. A normal citizen pays taxes, repays loans, goes to work, lives in a family and brings up children. In his every- day life, he has the right to expect the state to provide a peaceful life for him without dan- gers while he does his public burden payments. As for the individual, based on the Maslow pyramid, need of safety and defence have only the second place, which has an effect on the society as well. We cannot forget that the image of the state as provider is deeply ingrained in Hungarian culture, which also fosters this way of thinking. The product of defence adminis- tration is not tactile by people, who pay for it in public burdens, which means, in their point of view, it is a service provided by the state.

\section{Quality in defence administration}

Let us study the connection between quality and defence administration according to the chapters above. The base of the examination is a previous statement, which says that "quality is a bunch of properties which describe a given thing and it has to be examined from a given 
point of view". The point of view is described usually by a social need, obviously through a political direction. To some extent, of course there are some financial barrier to the system. How should defence administration work? What is expected from it?

- Basically, if we examine why this social and administrative system has been created, we can answer:

- It has to do its duty, which means it has to provide the complex security of the state.

- It has to be effective and sustainable.

- It has to react flexibly in terms of its function.

I asked a few people, not in a representative survey, but with my own questionnaire to describe according to priorities what social needs they can mention and are to be expected from defence administration and to draw up what can be the quality features of defence ad- ministration, and what they first thought of when they hear the expression: quality of defence administration.

For the first question, $77 \%$ of the people said information is the most important. The second place is shared between efficiency and fast reaction, while in third place prevention stands with $31 \%$. It is clear now that social need of the questioned people are the same as the operational needs of the system itself as it was mentioned above.

It is interesting that information was expected not only for the endangered period but for the defence administration itself so defence administration is not well-known by the usual people.

Provision of the complex state protection, as a principle is reflected in the fact that it was created through a centralized method. There are four categories according to the stages of centralization:

- Central,

- Rural,

- Local,

- Municipal.

The special law periods and its power centres are shown in the chart below:

Table 1. Special Legal Order Periods

\begin{tabular}{|c|c|c|}
\hline DESCRIPTION & CONTENT & POWER CENTER \\
\hline State of National Crisis & War, risk of war & Military Council \\
\hline State of Emergency & $\begin{array}{c}\text { Threat to law and order, } \\
\text { takeover of power }\end{array}$ & Government \\
\hline Unexpected Attack & Risk of an armed attack & Government \\
\hline State of Preventive Defence & $\begin{array}{c}\text { External armed attack or } \\
\text { duty to NATO }\end{array}$ & Government \\
\hline State of Danger & Natural or industrial disas- \\
\hline
\end{tabular}

Source: NAGY S. (Based on the Fundamental Law of Hungary) 
It can be seen on the designation of central levels, which are responsible for the control of acting against real dangers that even if there are some barriers in peace or normal periods, the financial sources have no upper limit in case of real prevention or damage control tasks. The system is based on administration, which means the human parts of the system get their wages by doing other usual, temporary tasks. In my opinion, there cannot be found a better way to efficiency but I have to return to this question when I analyse preventive tasks.

The ability of reaction to emergencies is speeded up by the reorganization of administra- tion and the establishment of government and district offices, although it is important to state that the time factor of reaction ability depends on the possibility to forecast a given danger. It means the system of defence administration has problems with time, which comes from the change-over of the normal period. However if the given danger is not forecasted in time, if the forecast time is longer than the time factor mentioned above, the fact of time will not appear for citizens. This is why we need the action before the reaction time, which can be called prevention. Axioms of prevention are:

- Prevention is based on mostly magisterial work (control);

- The base of magisterial work is careful and designed legislation.

Certainly we have to rely on compliance with law, but authority always has to have doubts, which can be proved or neglected based on inspections. Another question is that ex- cessive control has a negative effect in some cases and official sanctions can make authority a target of political attack in society. This field should be developed in countries formerly known as the Eastern Bloc.

The analysis of answers given to the second question showed a wider picture, $46 \%$ of the responders emphasized workmanship, reaction ability and efficiency; $31 \%$ of them men- tioned information; $23 \%$ of them think that the experience in handling real events is the most important.

All of them have been mentioned in my essay, their analysis is not necessary now but I have to mention one thing. Among the quality features of defence administration, the re-sponders mentioned experience in handling real events in the third place. Here we can see again the problem which was mentioned in connection with forecasts. Moreover, the analysis of past disasters shows that the different branches have a lot of experience in handling floods. It is obvious if the event can be forecasted, except the floods of river Tisza at the borders. The river Danube can be forecasted at a really early time. Situations which happen because of the extraordinary weather are different cases. In 2012, when the forecast happened in time, we were able to defend successfully against a heavy snow and terribly cold weather in the Southern Great Plain, but on the next occaisions we saw, that people — probably for political reasons — wrongly tried to blame disaster management for the snow situation on $15^{\text {th }}$ March in 2013.

\section{Summary}

Above, I have broadly mentioned quality and defence administration, then the definition of quality in the field of defence administration. We could see that quality means a bunch of features in every case, which has to be examined from a given point of view. The most em- phasized social need is information, efficiency, ability for fast reaction in case of emergency and prevention. 
It was also shown that defence administration is based on administration, which is con- trolled by effective political power. It means prevention even in official or other fields, like reacting or handling real situations can be a centre of political conflicts.

On the other hand, the Hungarian defence administration meets social expectations but there is no doubt that such statements are temporary in a continuously developing world and the quality of defence administration depends on changing social needs as well as a possible modification in administration.

\section{References}

[1] JUHÁSZ J. (1975): Hungarian Concise Dictionary. 2nd edition, Budapest: Academic Press. ISBN 9630507315

[2] BERÉNYI L. (Ed.) (2011): Basics of Quality. Miskolc: University of Miskolc, Institution of Leadership. www.szervez.uni-miskolc.hu/blaci/minmen/minsg_fogalma.html (downloaded: 2502 2014)

[3] SCHMIDT J. (1923): The "Ind" philosophy. Budapest: Genius Press, E-book, Terebess Ázsia, E-collection. www.terebess.hu/keletkultinfo/schmidt2.html (downloaded: 2402 2014)

[4] CROSBY, P. B. (1979): Quality is Free. New York: McGraw-Hill, ISBN 0070145121

[5] TAMÁS J., JUHÁSZ Cs., PREGUN Cs., NAGY A., SZŐLLŐSI N., GERÖCZI V., FLÓRIÁN T. (2011) Global Environmental Problems and their effects on society II. Debrecen: University of Debrecen, Centre of Agricultural and Economical Sciences.

www.tankonyvtar.hu/hu/tartalom/tamop425/0032_fogyasztovedelem/0032_fogyasztovedelem.pdf (downloaded: 1903 2014) 